\title{
Analisis dalam Melihat Perkembangan Indeks Harga Perdagangan Besar Menurut Sektor di Indonesia Menggunakan Algoritma Backpropagation
}

\author{
Zulfikar1, Anjar Wanto², Zulaini Masruro Nasution $^{3}$ \\ STIKOM Tunas Bangsa Pematangsiantar \\ Jl. Jend Sudirman BLOK A No 1, 2 \& 3 Pematangsiantar, 0622-22431 \\ zulfikaropick22@gmail.com ${ }^{1}$ \\ anjarwanto@amiktunasbangsa.ac.id ${ }^{2}$ \\ zulaini@amiktunasbangsa.ac.id ${ }^{3}$
}

\begin{abstract}
The Large Trade Price Index (IHPB) is one of the economic indicators that contains index numbers and shows changes in the price of goods purchased by traders from consumers. This study uses Artificial Neural Networks (ANN) with the Backpropagation method. Artificial neural networks are branches of artificial intelligence that mimic or imitate the workings of the human brain. The data of this study are secondary data sourced from the Central Statistics Agency (BPS) from 2000 to 2017. The data is divided into 2 parts, namely training data and testing data. There are 5 architectural models used in this study. 8 15-1, 8-25-1, 8-26-1, 8-30-1 and 8-40-1. From the 5 architectural models used 1 best model was obtained, namely 8-25-1 with an accuracy rate of 85\%, MSE 0.00100074 and 10000 iterations. So this model is good for predicting large trade price indexes according to sectors in Indonesia in the future.
\end{abstract}

Keywords: Large Trade Price Index, ANN, Prediction, Backpropagation

Abstrak - Indeks Harga Perdagang Besar (IHPB) merupakan salah satu indikator ekonomi yang memuat angka indeks dan menunjukkan perubahan pada harga pembelian barang oleh para pedagang dari konsumen. Penelitian ini menggunakan Jaringan Saraf Tiruan (JST) dengan metode Backpropagation. Jaringan syaraf tiruan merupakan cabang dari kecerdasan buatan yang meniru atau mencontoh cara kerja otak manusia. Data penelitian ini merupakan data sekunder yang bersumber dari Badan Pusat Statistik (BPS) dari tahun 2000 sampai tahun 2017. Data dibagi menjadi 2 bagian yakni data pelatihan dan data pengujian. Ada 5 model arsitektur yang digunakan pada penelitian ini. 8-15-1, 8-25-1, 826-1, 8-30-1 dan 8-40-1. Dari ke 5 model arsitektur yang digunakan diperoleh 1 model terbaik yaitu 8-25-1 dengan tingkat akurasi 85\%, MSE 0,00100074 dan iterasi 10000. Sehingga model ini bagus untuk memprediksi indeks harga perdagangan besar menurut sektor di Indonesia dimasa yang akan datang.

Kata kunci: Indeks Harga Perdagangan Besar, JST, Prediksi, Backpropagation.

\section{PENDAHULUAN}

Indeks Harga Perdagangan Besar (IHPB) adalah indeks yang mengukur ratarata perubahan harga antar waktu dari suatu paket jenis barang pada tingkat perdagangan besar atau penjualan secara partai besar. Indeks harga ini merupakan salah satu indikator untuk melihat perkembangan perekonomian secara umum serta sebagai bahan dalam analisa pasar dan moneter, dan disajikan dalam bentuk indeks umum dan juga sektoral yang meliputi pertanian, 
pertambangan dan penggalian, industri, impor, ekspor, migas dan nonmigas. Jumlah besar artinya tidak atau bukan eceran. Di sini memang sulit untuk menentukan tentang batasan jumlah besar di dalam suatu perdagangan, karena biasanya dilihat dari dua matra yang kadang-kadang tidak selalu bisa dipertemukan. Matra yang dimaksud adalah kuantitas dan nilai, pengertian jumlah besar tidak bisa diukur dengan kuantitas karena kuantitas yang besar belum tentu menjamin tingkat perdagangan besar [1].Pertumbuhan ekonomi yang terjadi di Indonesia cukup pesat dan telah mengubah pola pikir masyarakat di bidang ekonomi umumnya dan bidang indeks harga perdagangan besar pada khususnya [2]. Indeks Harga Perdagangan Besar (IHPB) merupakan salah satu indikator ekonomi yang memuat angka indeks dan menunjukkan perubahan pada harga pembelian barang oleh para pedagang besar dari konsumen. Harga perdagangan besar adalah harga transaksi yang terjadi antara penjual/pedagang besar pertama dengan pembeli/pedagang besar berikutnya dalam jumlah besar pada pasar pertama untuk suatu barang. Pedagang besar adalah pengusaha/pedagang yang menjual barang dalam jumlah besar untuk setiap jenis barang yang diperdagangkan (BPS 2018).

Dengan melihat perkembangan IHPB mereka bisa memperkirakan keadaan harga dimasa yang akan datang. Barang-barang yang dihitung dalam IHPB dikelompokkan ke dalam sektor-sektor tertentu dan tiap sektor dibagi menjadi beberapa subsektor yang meliputi pertanian, pertambangan dan penggalian, industri, impor, total ekspor meliputi ekspor nonmigas dan ekspor migas, indeks umum meliputi indeks umum tanpa ekspor migas, indeks umum tanpa ekspor, indeks umum tanpa impor, migas, indeks umum tanpa impor dan ekspor. Maka diperlukanya suatu keputusan untuk menentukan naik turunya IHPB dengan melakukan prediksi dengan jaringan saraf tiruan menggunakan algoritma backpropagation. Salah satu metode/algoritma yang baik digunakan untuk memperlihatkan suatu data time series adalah metode backpropagation.

\section{METODOLOGI PENELITIAN}

\subsection{Jaringan Saraf Tiruan}

Jaringan Syaraf Tiruan merupakan salah satu representasi buatan dari otak manusia yang selalu mencoba untuk mensimulasikan proses pembelajaran pada otak manusia tersebut [3]-[5]. Istilah buatan disini digunakan karena jaringan syaraf ini diimplemintasikan dengan menggunakan program komputer yang mampu menyelesaikan sejumlah proses perhitungan selama proses pembelajaran. Model struktur jaringan saraf tiruan dapat dilihat pada gambar 2.1.

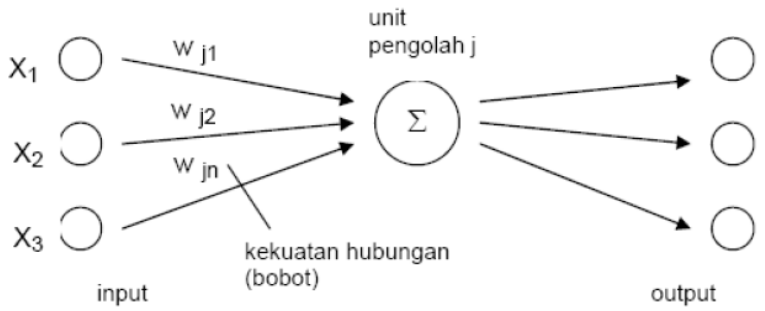

(Sumber : Windarto, Lubis, dan Solikhun, 2018 [6])

Gambar 1. Model Struktur Jaringan Saraf Tiruan 


\subsection{Algoritma Backpropagation}

Propagasi balik atau back-propagation merupakan salah satu teknik pembelajaran/pelatihan supervised learning yang paling banyak digunakan. Metode ini merupakan salah satu metode yang sangat baik dalam menangani masalah pengenalan pola-pola kompleks. Di dalam jaringan propagasi balik, setiap unit yang berada di lapisan input terhubung dengan setiap unit yang ada di lapisan tersembunyi. Setiap unit yang ada di lapisan tersembunyi terhubung dengan setiap unit yang ada di lapisan output. Jaringan ini terdiri dari banyak lapisan (multilayer network). Ketika jaringan diberikan pola masukan sebagai pola pelatihan, maka pola tersebut menuju unit-unit lapisan tersembunyi untuk selanjutnya diteruskan pada unit-unit di lapisan keluaran [6]. Metode ini bekerja melalui proses secara iteratif dengan menggunakan sekumpulan contoh data (data training), membandingkan nilai prediksi dari jaringan dengan setiap contoh. Dalam setiap proses, bobot relasi dalam jaringan dimodifikasi untuk meminimalkan nilai Mean Square Error (MSE) antara nilai prediksi dari jaringan dengan nilai sesungguhnya. Modifikasi relasi ANN tersebut dilakukan dengan arah mundur, dari layer keluaran hingga layer pertama dari layer hidden sehingga metode ini disebut sebagai back propagation

\subsection{Model Arsitektur Backpropagation}

Backpropagation merupakan jaringan dengan lapisan jamak (multilayer network) yang memiliki ciri khas tertentu yaitu memiliki 3 jenis layer yakni layer input, layer tersembunyi, layer output. Backpropagation dapat menyelesaikan permasalahan yang kompleks dibandingkan dengan metode/algoritma yang lainnya [7]-[13].

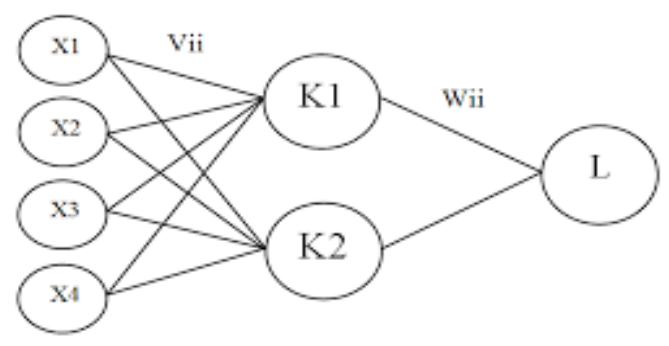

Keterangan :

Gambar 2. Model Arsitektur Backpropagation

Arsitektur jaringan yang digunakan dapat dilihat pada Gambar 2.4. yang terdiri dari tiga lapisan, yaitu : 4 lapis masukan (input), 2 lapis tersembunyi (hidden layer), dan 1 lapis keluaran (output). Dari gambar 2.3. dapat dijelaskan bahwa arsitektur backpopagation dengan $n$ buah masukkan $\left(\mathrm{x}_{1}, \mathrm{x}_{2}, \mathrm{x}_{3}, \ldots . ., \mathrm{x}_{\mathrm{n}}\right)$ ditambah sebuah bias, sebuah lapisa tersembunyi yang terdiri dari $j$ unit tambahan sebuah bias, serta $k$ buah unit keluaran.

Setiap pola-pola informasi input dan output yang diberikan pada jaringan syaraf tiruan diproses dalam neuron. Neuron-neuron tersebut terkumpul didalam lapisan-lapisan yang disebut neuron layers. Lapisan-lapisan penyusun jaringan syaraf tiruan tersebut dapat dibagi menjadi tiga (3) [14][15], yaitu : 
1. Lapisan input.

Unit-unit di dalam lapisan input disebut unit-unit input. Unit-unit input tersebut menerima pola inputan data dari luar yang menggambarkan suatu permasalahan.

2. Lapisan tersembunyi.

Unit-unit di dalam lapisan tersembunyi disebut unit-unit tersembunyi. Dimana outputnya tidak langsung dapat diamati.

3. Lapisan output.

Unit-unit di dalam lapisan output disebut unit-unit output. Output dari lapisan ini merupakan solusi jaringan syaraf tiruan terhadap suatu permasalahan.

\section{HASIL DAN PEMBAHASAN}

\subsection{Normalisasi Data}

Dalam melakukan pelatihan dan pengujian, terlebih dahulu dilakukan normalisasi untuk mempermudah melakukan pelatihan dan pengujian data. Formula normalisasi dapat dilihat pada persamaan berikut [16]-[29]:

$$
\mathrm{x}^{\prime}=\frac{0.8(x-a)}{b-a}+0.1
$$

Tabel 1. Data Training Awal (2000-2007)/ Target Tahun 2008

\begin{tabular}{|c|c|c|c|c|c|c|c|c|c|}
\hline $\begin{array}{c}\text { Kelompok } \\
\text { Komoditi IHPB }\end{array}$ & 000 & 2001 & 002 & 2003 & 2004 & 2005 & 2006 & 2007 & Target \\
\hline 1.Pertanian & 0,00 & & 25,36 & & 37,40 & 148,23 & & 13,99 & 74,94 \\
\hline $\begin{array}{l}\text { 2.Pertamba } \\
\text { Penggalian }\end{array}$ & 00,00 & 08,32 & 121,49 & 123,44 & 34,60 & 147,06 & 68,64 & 187,33 & 2332 \\
\hline 3.Industri & 0 & 69 & 2 & 33 & 72 & 13 & & 3,28 & \\
\hline 4.Impor & 0,00 & 20 & 111,73 & 114,33 & 127,24 & 148,57 & 36 & 186,26 & 94 \\
\hline Total E & & & 108,11 & 108,50 & 21,23 & 146,04 & 62 & 166,89 &, 36 \\
\hline a.Ekspor & 0,00 & 1,81 & 108,74 & 106,50 & 112,44 & 124,51 & & 143,06 & 97 \\
\hline b.Ekspor Mi & 100,00 & 113,56 & 106,13 & 114,75 & 148,63 & 209,92 & 228,76 & 241,23 & 4,67 \\
\hline Indeks Umu & 0,00 & 12,70 & 117,79 & 121,57 & 130,60 & 151,40 & 70 & 195,17 &, 56 \\
\hline $\begin{array}{l}\text { Indeks Ur } \\
\text { Ekspor M }\end{array}$ & 00,00 & 112,87 & 121,30 & 126,32 & 134,01 & 153,63 & 179,45 & 207,30 & 1,09 \\
\hline $\begin{array}{l}\text { Indeks Umu } \\
\text { Ekspor } \\
\end{array}$ & 00,00 & 12,64 & 118,59 & 122,04 & 129,36 & 147,34 & 21 & 191,56 &, 78 \\
\hline $\begin{array}{l}\text { Indeks Umum Tanpa } \\
\text { Impor }\end{array}$ & 00,00 & 12,39 & 119,05 & 123,09 & 131,31 & 151,99 & 173,96 & 197,33 & 13 \\
\hline $\begin{array}{l}\text { Indeks Umum Tanpa } \\
\text { Impor dan Ekspor } \\
\text { Migas }\end{array}$ & 00,00 & 112,29 & 120,15 & 123,79 & 129,84 & 147,07 & 168,50 & 192,97 & 238,53 \\
\hline $\begin{array}{l}\text { Indeks Umum Tanpa } \\
\text { Impor dan Ekspor }\end{array}$ & 00,00 & 112,46 & 124,26 & 130,02 & 136,10 & 155,19 & 186,04 & 215,41 & 271,17 \\
\hline
\end{tabular}

Tabel 2. Data Training Setelah Dinormalisasi (2000-2007)/ Target Tahun 2008

\begin{tabular}{|c|c|c|c|c|c|c|c|c|c|}
\hline $\begin{array}{c}\text { Kelompok } \\
\text { Komoditi IHPB }\end{array}$ & 2000 & 2001 & 2002 & 2003 & 2004 & 2005 & 2006 & 2007 & Target \\
\hline 1.Pertanian & 0,10000 & 0,15199 & 0,18645 & 0,20285 & 0,22750 & 0,26442 & 0,34412 & 0,48860 & 0,69638 \\
\hline $\begin{array}{l}\text { 2.Pertambangan } \\
\text { dan Penggalian }\end{array}$ & 0,10000 & 0,12836 & 0,17326 & 0,17991 & 0,21795 & 0,26043 & 0,33400 & 0,39771 & 0,52040 \\
\hline
\end{tabular}




\begin{tabular}{|l|c|c|c|c|c|c|c|c|c|}
\hline \multicolumn{1}{|c|}{$\begin{array}{c}\text { Kelompok } \\
\text { Komoditi IHPB }\end{array}$} & $\mathbf{2 0 0 0}$ & $\mathbf{2 0 0 1}$ & $\mathbf{2 0 0 2}$ & $\mathbf{2 0 0 3}$ & $\mathbf{2 0 0 4}$ & $\mathbf{2 0 0 5}$ & $\mathbf{2 0 0 6}$ & $\mathbf{2 0 0 7}$ & Target \\
\hline 3.Industri & 0,10000 & 0,13985 & 0,18189 & 0,20340 & 0,22177 & 0,29817 & 0,42236 & 0,50322 & 0,68963 \\
\hline 4.Impor & 0,10000 & 0,14841 & 0,13999 & 0,14885 & 0,19286 & 0,26558 & 0,31259 & 0,39406 & 0,56002 \\
\hline 5.Total Ekspor & 0,10000 & 0,14169 & 0,12765 & 0,12898 & 0,17237 & 0,25695 & 0,28279 & 0,32803 & 0,47281 \\
\hline a.Ekspor Non Migas & 0,10000 & 0,14026 & 0,12980 & 0,12216 & 0,14241 & 0,18356 & 0,20063 & 0,24679 & 0,32489 \\
\hline b.Ekspor Migas & 0,10000 & 0,14623 & 0,12090 & 0,15028 & 0,26578 & 0,47472 & 0,53895 & 0,58146 & 0,90000 \\
\hline Indeks Umum & 0,10000 & 0,14329 & 0,16065 & 0,17353 & 0,20432 & 0,27522 & 0,34443 & 0,42444 & 0,59622 \\
\hline $\begin{array}{l}\text { Indeks Umum } \\
\text { Tanpa Ekspor } \\
\text { Migas }\end{array}$ & 0,10000 & 0,14387 & 0,17261 & 0,18973 & 0,21594 & 0,28283 & 0,37085 & 0,46579 & 0,64916 \\
\hline $\begin{array}{l}\text { Indeks Umum } \\
\text { Tanpa Ekspor }\end{array}$ & 0,10000 & 0,14309 & 0,16337 & 0,17514 & 0,20009 & 0,26138 & 0,32912 & 0,41213 & 0,56970 \\
\hline $\begin{array}{l}\text { Indeks Umum } \\
\text { Tanpa Impor }\end{array}$ & 0,10000 & 0,14224 & 0,16494 & 0,17871 & 0,20674 & 0,27724 & 0,35213 & 0,43180 & 0,60498 \\
\hline $\begin{array}{l}\text { Indeks Umum } \\
\text { Tanpa Impor dan } \\
\text { Ekspor Migas }\end{array}$ & 0,10000 & 0,14190 & 0,16869 & 0,18110 & 0,20173 & 0,26046 & 0,33352 & 0,41694 & 0,57225 \\
$\begin{array}{l}\text { Indeks Umum } \\
\text { Tanpa Impor dan } \\
\text { Ekspor }\end{array}$ & 0,10000 & 0,14248 & 0,18270 & 0,20234 & 0,22307 & 0,28815 & 0,39331 & 0,49344 & 0,68353 \\
\hline
\end{tabular}

Tabel 3. Data Testing Awal (2009-2016)/ Target Tahun 2017

\begin{tabular}{|l|c|c|c|c|c|c|c|c|c|}
\hline \multicolumn{1}{|c|}{$\begin{array}{c}\text { Kelompok } \\
\text { Komoditi IHPB }\end{array}$} & $\mathbf{2 0 0 9}$ & $\mathbf{2 0 1 0}$ & $\mathbf{2 0 1 1}$ & $\mathbf{2 0 1 2}$ & $\mathbf{2 0 1 3}$ & $\mathbf{2 0 1 4}$ & $\mathbf{2 0 1 5}$ & $\mathbf{2 0 1 6}$ & Target \\
\hline $\begin{array}{l}\text { 1.Pertanian } \\
\text { 2.Pertambangan dan } \\
\text { Penggalian }\end{array}$ & 208,84 & 231,43 & 248,78 & 263,25 & 287,44 & 175,05 & 240,68 & 358,41 & 369,68 \\
\hline 3.Industri & 164,79 & 172,01 & 180,32 & 187,48 & 194,09 & 122,83 & 128,89 & 133,92 & 138,65 \\
\hline 4.Impor & 156,61 & 160,90 & 177,37 & 189,17 & 199,25 & 137,37 & 134,19 & 128,10 & 135,00 \\
\hline 5.Total Ekspor & 134,10 & 137,80 & 154,11 & 163,15 & 168,71 & 138,73 & 130,47 & 133,31 & 144,69 \\
\hline a.Ekspor Non Migas & 142,41 & 142,05 & 148,03 & 153,15 & 157,95 & 129,07 & 136,98 & 146,11 & 151,85 \\
\hline $\begin{array}{l}\text { b.Ekspor Migas } \\
\text { Indeks Umum }\end{array}$ & 108,16 & 124,52 & 173,11 & 194,38 & 202,32 & 168,10 & 110,65 & 94,42 & 122,90 \\
\hline $\begin{array}{l}\text { Indeks Umum Tanpa } \\
\text { Ekspor Migas }\end{array}$ & 171,10 & 180,20 & 183,91 & 192,59 & 201,93 & 130,47 & 139,78 & 152,18 & 157,92 \\
\hline $\begin{array}{l}\text { Indeks Umum Tanpa } \\
\text { Ekspor }\end{array}$ & 165,71 & 173,27 & 191,88 & 201,35 & 211,70 & 130,76 & 140,35 & 153,41 & 159,14 \\
\hline $\begin{array}{l}\text { Indeks Umum Tanpa } \\
\text { Impor }\end{array}$ & 163,99 & 172,62 & 184,56 & 193,43 & 202,52 & 131,43 & 139,12 & 153,62 & 160,55 \\
\hline $\begin{array}{l}\text { Indeks Umum Tanpa } \\
\text { Impor dan Ekspor } \\
\text { Migas }\end{array}$ & 167,74 & 176,05 & 185,38 & 193,36 & 202,54 & 128,95 & 141,04 & 157,62 & 163,10 \\
\hline $\begin{array}{l}\text { Indeks Umum Tanpa } \\
\text { Impor dan Ekspor }\end{array}$ & 175,29 & 185,79 & 196,07 & 204,87 & 215,31 & 128,91 & 142,09 & 160,60 & 166,01 \\
\hline
\end{tabular}

Tabel 4. Data Testing Setelah Dinormalisasi (2009-2016)/ Target Tahun 2017

\begin{tabular}{|l|c|c|c|c|c|c|c|c|c|}
\hline $\begin{array}{l}\text { Kelompok } \\
\text { Komoditi IHPB }\end{array}$ & $\mathbf{2 0 0 9}$ & $\mathbf{2 0 1 0}$ & $\mathbf{2 0 1 1}$ & $\mathbf{2 0 1 2}$ & $\mathbf{2 0 1 3}$ & $\mathbf{2 0 1 4}$ & $\mathbf{2 0 1 5}$ & $\mathbf{2 0 1 6}$ & Target \\
\hline $\begin{array}{l}\text { 1.Pertanian } \\
\text { 2.Pertambangan } \\
\text { dan Penggalian }\end{array}$ & $0,432540,498200,548620,59068$ & 0,66098 & $0,334340,52508$ & 0,86725 & 0,90000 \\
\hline 3.Industri & $0,304520,325500,349650,37046$ & 0,38968 & $0,182570,20018$ & 0,21480 & 0,22855 \\
\hline 4.Impor & $0,280750,293210,341080,37538$ & 0,40467 & $0,224830,21559$ & 0,19789 & 0,21794 \\
\hline
\end{tabular}




\begin{tabular}{|l|l|l|l|l|l|l|l|}
\hline 5.Total Ekspor & $0,215320,226080,273480,29975$ & 0,31591 & $0,228780,20477$ & 0,21303 & 0,24610 \\
\hline $\begin{array}{l}\text { a.Ekspor Non } \\
\text { Migas }\end{array}$ & $0,239480,238430,25581$ & 0,27069 & 0,28464 & $0,200700,22369$ & 0,25023 & 0,26691 \\
\hline b.Ekspor Migas & $0,139930,187480,328700,39052$ & 0,41359 & $0,314140,14717$ & 0,10000 & 0,18277 \\
\hline Indeks Umum & $0,298470,321380,358340,38561$ & 0,41252 & $0,210500,22741$ & 0,25909 & 0,27923 \\
\hline $\begin{array}{l}\text { Indeks Umum } \\
\text { Tanpa Ekspor } \\
\text { Migas }\end{array}$ & $0,322860,349310,360090,38532$ & 0,41246 & $0,204770,23183$ & 0,26787 & 0,28455 \\
\hline $\begin{array}{l}\text { Indeks Umum } \\
\text { Tanpa Ekspor }\end{array}$ & $0,307190,329170,383250,41078$ & 0,44086 & $0,205620,23349$ & 0,27145 & 0,28810 \\
\hline $\begin{array}{l}\text { Indeks Umum } \\
\text { Tanpa Impor }\end{array}$ & $0,302190,327280,361980,38776$ & 0,41418 & $0,207560,22991$ & 0,27206 & 0,29220 \\
\hline $\begin{array}{l}\text { Indeks Umum } \\
\text { Tanpa Impor dan } \\
\text { Ekspor Migas }\end{array}$ & $0,313090,337240,364360,38755$ & 0,41423 & $0,200360,23549$ & 0,28368 & 0,29961 \\
\hline $\begin{array}{l}\text { Indeks Umum } \\
\text { Tanpa Impor dan } \\
\text { Ekspor }\end{array}$ & $0,335040,365550,395430,42101$ & 0,45135 & $0,200240,23855$ & 0,29234 & 0,30807 \\
\hline
\end{tabular}

\subsection{Analisis}

Setelah dilakukan normalisasi, maka akan dilakukan pelatihan menggunakan software Matlab R2011b. Adapun parameter-parameter yang diperlukan dalam proses pelatihan adalah sebagai berikut:

$>>$ net=newff(minmax (P),[Hiden,Hidden,Target],\{'tansig','purelin','tansig'\},'traingd');

$>$ net.IW $\{1,1\}$;

$>>$ net.b $\{1\}$;

$>$ net.LW $\{2,1\}$;

$>$ net.b $\{2\}$;

$>$ net.LW $\{3,2\}$;

$>$ net.trainparam.epochs $=100000$;

$>$ net.trainparam. $L R=0.01$;

$>$ net.trainParam.goal $=0.001$;

$>$ net.trainParam.show $=1000$;

$>$ net. $b\{3\}$;

$>$ net=train $($ net $, P, T)$;

\subsection{Pelatihan dan Pengujian Data}

Pada penelitian ini menggunakan 5 (lima) model arsitektur pelatihan dan pengujian data yakni 8-15-1, 8-25-1, 8-26-1, 8-30-1 dan 8-40-1. Berdasarkan model arsitektur 8-15-1 dapat dijabarkan bahwa 8 merupakan data neuron input layer, 15 merupakan data neuron hidden layer dan 1 merupakan data neuron output layer, begitu pula halnya dengan keterangan model arsitektur yang lain. Arsitektur terbaiknya yaitu 8-25-1 dengan tingkat akurasi sebesar 85\%. Dapat dilihat pada tabel 3.5. berikut. 
Tabel 5. Arsitektur Algoritma Backpropagation

\begin{tabular}{|c|c|c|c|c|c|c|}
\hline \multirow{2}{*}{ No } & \multirow{2}{*}{ Arsitektur } & \multicolumn{3}{|c|}{ Training } & \multicolumn{2}{c|}{ Testing } \\
\cline { 3 - 7 } & & Epoch & Waktu & MSE & MSE & Akurasi \\
\hline 1 & $8-15-1$ & 4764 & 00.49 & 0,00099956 & 1,57408921 & $8 \%$ \\
\hline 2 & $8-25-1$ & 1184 & 00.14 & 0,00100074 & 0,11564972 & $85 \%$ \\
\hline 3 & $8-26-1$ & 3089 & 00.34 & 0,00099917 & 0,24325816 & $38 \%$ \\
\hline 4 & $8-30-1$ & 1187 & 00.15 & 0,00099937 & 0,27290747 & $31 \%$ \\
\hline 5 & $8-40-1$ & 2360 & 00.21 & 0,00099941 & 0,79647449 & $69 \%$ \\
\hline
\end{tabular}

Berdasarkan tabel 3.5. tingkat akurasi pengujian 5 model arsitektur maka dapat disimpulkan bahwa model arsitektur 8-25-1 dengan epoch sebesar 1184 iterasi dalam waktu 00.14 detik menghasilkan tingkat akurasi yakni sebesar $85 \%$ merupakan model arsitektur terbaik untuk digunakan dalam propses prediksi tahun berikutnya.

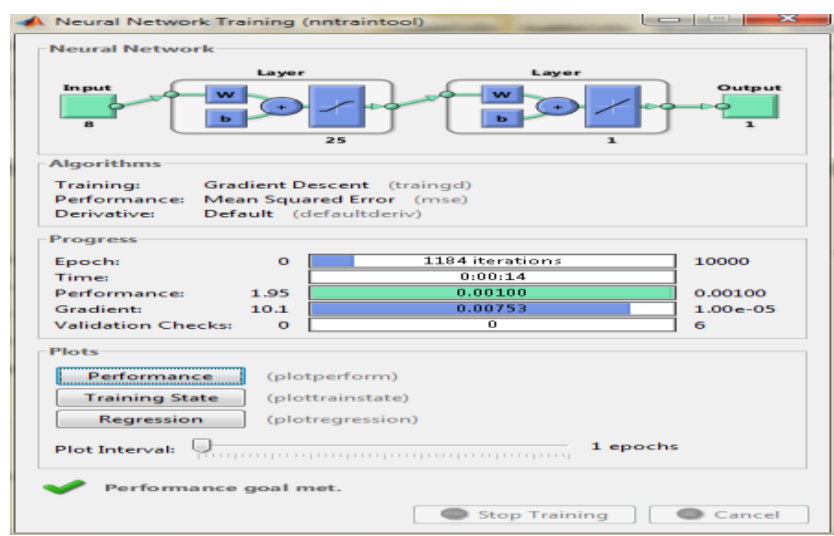

Gambar 3. Hasil Data Pelatihan Dengan Arsitektur 8-25-1

Dari gambar model arsitektur 8-25-1 diatas dapat dijelaskan bahwa Epoch yang terjadi sebesar 1184 dengan lama waktu 14 detik.

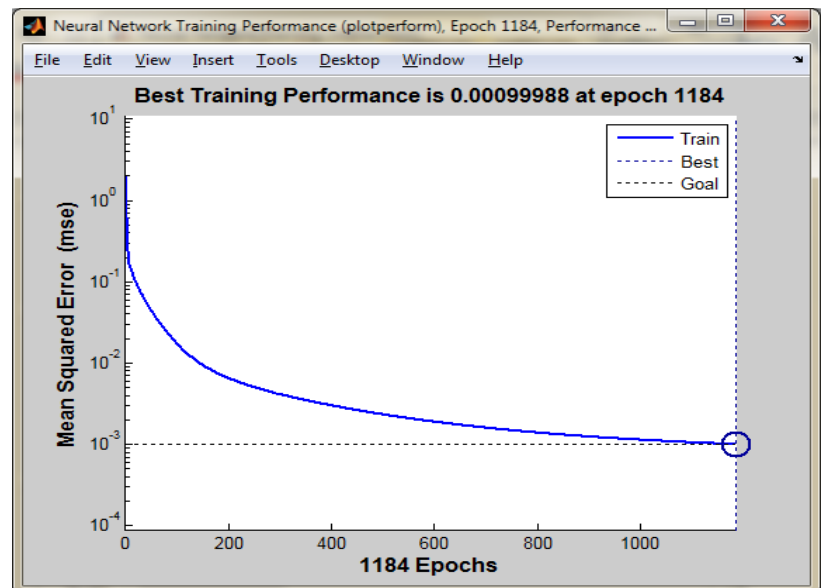

Gambar 4. Hasil Epoch Pelatihan Dengan Arsitektur 8-25-1

Dari gambar model arsitektur 8-25-1 dijelaskan bahwa dari Epoch pelatihan dapat diperoleh Mean Square Error (MSE) sebesar 0,00100074. 
Tabel 6. Arsitektur Terbaik Backpropagation 8-25-1

\begin{tabular}{|c|c|c|c|c|c|c|c|c|}
\hline \multicolumn{4}{|c|}{ Data Training } & \multicolumn{5}{|c|}{ Data Testing } \\
\hline Pola & Target & Output Error & SSE & Target & Output & Error & SSE & Hasil \\
\hline Pola 1 & 0,69638 & $0,72070-0,02432$ & 0,00059156 & 0,90000 & 0,51630 & 0,38370 & 0,14722569 & 0 \\
\hline Pola2 & 0,52040 & $0,499500,02090$ & 0,00043694 & 0,17748 & 30,51630 & $-0,33882$ & 0,11479689 & 1 \\
\hline Pola 3 & 0,68963 & $0,73070-0,04107$ & 0,00168691 & 0,22855 & 0,51630 & $-0,2$ & 0,08280147 & 1 \\
\hline Pola 4 & 0,56002 & $0,518400,04162$ & 0,00173191 & 0,21794 & 0,5 & $t^{-}$ & 0,08884012 & 1 \\
\hline Pola 5 & 0,47281 & $0,50890-0,03609$ & 0,00130228 & 0,24610 & 0,48160 & 0 & 0,05545937 & 1 \\
\hline Pola 6 & 0,32489 & $0,33250-0,00761$ & 0,00005784 & 0,26691 & 0,513 & - & 0,06075669 & 1 \\
\hline Pola 7 & 0,90000 & $0,90150-0,00150$ & 0,00000225 & 0,18277 & 0,62410 & 0,80687 & 0,65104348 & 0 \\
\hline Pola 8 & 0,59622 & $0,584400,01182$ & 0,00013972 & 0,27923 & 0,51630 & $-0,23707$ & 0,05620020 & 1 \\
\hline Pola 9 & 0,64916 & $0,68310-0,03394$ & 0,00115174 & 0,28455 & 0,51630 & $-0,23175$ & 0,05370677 & 1 \\
\hline Pola 10 & 0,56970 & $0,521600,04810$ & 0,00231341 & 0,28810 & 0,51630 & $-0,22820$ & 0,05207591 & 1 \\
\hline Pola 11 & 0,60498 & $0,63030-0,02532$ & 0,00064103 & 0,29220 & 0,51630 & $-0,22410$ & 0,05022239 & 1 \\
\hline Pola 12 & 0,57225 & $0,58110-0,00885$ & 0,00007824 & 0,29961 & 0,51630 & $-0,2$ & 0,04695558 & 1 \\
\hline Pola 13 & 0,6835 & $0,629900,05363$ & 0,002 & 0,3080 & 70,5163 & $-0,20823$ & 0,04336177 & 1 \\
\hline & & & 0,013 & & & Jlh SSE & 1,50344633 & $85 \%$ \\
\hline & & MSE & 0,00100074 & & & MSE & 0,11564972 & \\
\hline
\end{tabular}

Keterangan :

$1=$ Benar $0=$ Salah

Tabel 7. Hasil Prediksi 5 Tahun Kedepan Dengan Backpropagation (2018-2022)

\begin{tabular}{|l|c|c|c|c|c|}
\hline \multicolumn{1}{|c|}{ Kelompok Komoditi IHPB } & $\mathbf{2 0 1 8}$ & $\mathbf{2 0 1 9}$ & $\mathbf{2 0 2 0}$ & $\mathbf{2 0 2 1}$ & $\mathbf{2 0 2 2}$ \\
\hline 1.Pertanian & 371,17 & 373,04 & 375,97 & 379,24 & 382,37 \\
\hline 2.Pertambangan dan Penggalian & 144,67 & 181,64 & 242,71 & 311,30 & 363,42 \\
\hline 3.Industri & 182,61 & 232,21 & 262,75 & 311,64 & 366,42 \\
\hline 4.Impor & 167,51 & 206,81 & 274,99 & 329,30 & 367,42 \\
\hline 5.Total Ekspor & 179,53 & 230,59 & 271,41 & 324,11 & 363,95 \\
\hline a.Ekspor Non Migas & 157,90 & 179,59 & 241,50 & 314,46 & 368,52 \\
\hline b.Ekspor Migas & 144,39 & 182,60 & 236,66 & 307,81 & 364,00 \\
\hline Indeks Umum & 173,19 & 200,63 & 264,78 & 318,10 & 368,17 \\
\hline Indeks Umum Tanpa Ekspor Migas & 164,77 & 209,45 & 259,71 & 333,34 & 363,08 \\
\hline Indeks Umum Tanpa Ekspor & 182,61 & 214,77 & 262,12 & 319,85 & 369,07 \\
\hline Indeks Umum Tanpa Impor & 175,59 & 202,05 & 263,07 & 316,24 & 368,38 \\
\hline Indeks Umum Tanpa Impor dan Ekspor Migas & 175,93 & 215,40 & 261,76 & 327,65 & 366,93 \\
\hline Indeks Umum Tanpa Impor dan Ekspor & 184,41 & 217,35 & 254,97 & 319,67 & 365,13 \\
\hline
\end{tabular}

\section{KESIMPULAN}

Kesimpulan yang dapat diambil dari penelitian ini antara lain :

a. Hasil prediksi perkembangan indeks harga perdagangan besar menurut sektor di Indonesia mengalami peningkatan yang cukup stabil dibanding peningkatan sebelumnya.

b. Setelah dilakukan pelatihan dan pengujian menggunakan 5 model arsitektur yakni 8-15-1, 8-25-1, 8-26-1, 8-30-1 dan 8-40-1, maka didapatkan 1 arsitektur terbaik dengan model 8-25-1 yang memiliki tingkat akurasi tertinggi yaitu sebesar 85\% dan dengan learning rate 0,05, jumlah iterasi sebanyak 1184 dengan waktu 00:14 detik dan Mean Squared Error (MSE) 0,11564972.

c. Pemilihan model arsitektur terbaik sangat berpengaruh untuk mendapatkan tingkat keakurasian yang optimal. 


\section{DAFTAR PUSTAKA}

[1] A. A. P. Y. Putra and I. W. W. Kesumajaya, "PENGARUH PRODUKSI, INDEKS HARGA PERDAGANGAN BESAR DAN KURS DOLLAR AMERIKA SERIKAT TERHADAP EKSPOR KAYU LAPIS DI INDONESIA," E-Jurnal EP Unud, vol. 6, no. 8, pp. 1544-1572, 2017.

[2] S. Idris, R. Goejantoro, and Y. N. Nasution, "Pemodelan Dan Peramalan Indeks Harga Perdagangan Besar (IHPB) Dengan Menggunakan ARFIMA," Jurnal EKSPONENSIAL Volume, vol. 5, no. 2, pp. 137-146, 2014.

[3] A. Wanto and A. P. Windarto, "Analisis Prediksi Indeks Harga Konsumen Berdasarkan Kelompok Kesehatan Dengan Menggunakan Metode Backpropagation," Jurnal \& Penelitian Teknik Informatika Sinkron, vol. 2, no. 2, pp. 37-44, 2017.

[4] A. Wanto, A. P. Windarto, D. Hartama, and I. Parlina, "Use of Binary Sigmoid Function And Linear Identity In Artificial Neural Networks For Forecasting Population Density," International Journal of Information System \& Technology, vol. 1, no. 1, pp. 43-54, 2017.

[5] A. Wanto, M. Zarlis, Sawaluddin, and D. Hartama, "Analysis of Artificial Neural Network Backpropagation Using Conjugate Gradient Fletcher Reeves in the Predicting Process," Journal of Physics: Conference Series, vol. 930, no. 1, pp. 1-7, 2017.

[6] A. P. Windarto, M. R. Lubis, and Solikhun, "MODEL ARSITEKTUR NEURAL NETWORK DENGAN BACKPROPOGATION PADA PREDIKSI TOTAL LABA RUGI KOMPREHENSIF BANK UMUM KONVENSIONAL," Kumpulan jurnaL Ilmu Komputer (KLIK), vol. 5, no. 2, pp. 147-158, 2018.

[7] S. P. Siregar and A. Wanto, "Analysis of Artificial Neural Network Accuracy Using Backpropagation Algorithm In Predicting Process (Forecasting)," International Journal of Information System \& Technology, vol. 1, no. 1, pp. 34-42, 2017.

[8] J. R. Saragih, M. Billy, S. Saragih, and A. Wanto, "Analisis Algoritma Backpropagation Dalam Prediksi Nilai Ekspor (Juta USD)," Jurnal Pendidikan Teknologi dan Kejuruan, vol. 15, no. 2, pp. 254-264, 2018.

[9] E. Hartato, D. Sitorus, and A. Wanto, "Analisis Jaringan Saraf Tiruan Untuk Prediksi Luas Panen Biofarmaka di Indonesia," Jurnal semanTIK, vol. 4, no. 1, pp. 49-56, 2018.

[10] S. Setti and A. Wanto, "Analysis of Backpropagation Algorithm in Predicting the Most Number of Internet Users in the World," JOIN (Jurnal Online Informatika), vol. 3, no. 2, pp. 110-115, 2018.

[11] R. E. Pranata, S. P. Sinaga, and A. Wanto, "Estimasi Wisatawan Mancanegara Yang Datang ke Sumatera Utara Menggunakan Jaringan Saraf," Jurnal semanTIK, vol. 4, no. 1, pp. 97-102, 2018.

[12] A. A. Fardhani, D. Insani, N. Simanjuntak, and A. Wanto, "Prediksi Harga Eceran Beras Di Pasar Tradisional Di 33 Kota Di Indonesia Menggunakan Algoritma Backpropagation," Jurnal Infomedia, vol. 3, no. 1, pp. 25-30, 2018.

[13] J. Wahyuni, Y. W. Paranthy, and A. Wanto, "Analisis Jaringan Saraf Dalam Estimasi Tingkat Pengangguran Terbuka Penduduk Sumatera Utara," Jurnal Infomedia, vol. 3, no. 1, pp. 18-24, 2018.

[14] Y. A. Lesnussa, S. Latuconsina, and E. R. Persulessy, "Aplikasi Jaringan Saraf Tiruan Backpropagation untuk Memprediksi Prestasi Siswa SMA ( Studi kasus : Prediksi Prestasi Siswa SMAN 4 Ambon )," Jurnal Matematika Integratif, vol. 11, no. 2, pp. 149-160, 2015.

[15] M. A. Razak and E. Riksakomara, "Peramalan Jumlah Produksi Ikan dengan Menggunakan Backpropagation Neural Network (Studi Kasus: UPTD Pelabuhan Perikanan Banjarmasin," JURNAL TEKNIK ITS, vol. 6, no. 1, pp. 142-148, 2017.

[16] A. Wanto et al., "Levenberg-Marquardt Algorithm Combined with Bipolar Sigmoid Function to Measure Open Unemployment Rate in Indonesia," in Conference Paper, 2018, pp. 1-7.

[17] I. A. R. Simbolon, F. Yatussa'ada, and A. Wanto, "Penerapan Algoritma Backpropagation dalam Memprediksi Persentase Penduduk Buta Huruf di Indonesia," Jurnal Informatika Upgris, vol. 4, no. 2, pp. 163-169, 2018.

[18] S. P. Siregar, A. Wanto, and Z. M. Nasution, "Analisis Akurasi Arsitektur JST Berdasarkan Jumlah Penduduk Pada Kabupaten / Kota di Sumatera Utara," in Seminar Nasional Sains \& Teknologi Informasi (SENSASI), 2018, pp. 526-536.

[19] A. Wanto, "Optimasi Prediksi Dengan Algoritma Backpropagation Dan Conjugate Gradient 
Beale-Powell Restarts," Jurnal Teknologi dan Sistem Informasi, vol. 3, no. 3, pp. 370-380, Jan. 2018.

[20] B. K. Sihotang and A. Wanto, "Analisis Jaringan Syaraf Tiruan Dalam Memprediksi Jumlah Tamu Pada Hotel Non Bintang," Jurnal Teknologi Informasi Techno, vol. 17, no. 4, pp. 333346, 2018.

[21] M. A. P. Hutabarat, M. Julham, and A. Wanto, "Penerapan Algoritma Backpropagation Dalam Memprediksi Produksi Tanaman Padi Sawah Menurut Kabupaten/Kota di Sumatera Utara," Jurnal semanTIK, vol. 4, no. 1, pp. 77-86, 2018.

[22] Y. Andriani, H. Silitonga, and A. Wanto, "Analisis Jaringan Syaraf Tiruan untuk prediksi volume ekspor dan impor migas di Indonesia," Register - Jurnal Ilmiah Teknologi Sistem Informasi, vol. 4, no. 1, pp. 30-40, 2018.

[23] A. Wanto, "Penerapan Jaringan Saraf Tiruan Dalam Memprediksi Jumlah Kemiskinan Pada Kabupaten/Kota Di Provinsi Riau," Kumpulan jurnaL Ilmu Komputer (KLIK), vol. 5, no. 1, pp. 61-74, 2018.

[24] I. S. Purba and A. Wanto, "Prediksi Jumlah Nilai Impor Sumatera Utara Menurut Negara Asal Menggunakan Algoritma Backpropagation," Jurnal Teknologi Informasi Techno, vol. 17, no. 3, pp. 302-311, 2018.

[25] A. Wanto, "Prediksi Angka Partisipasi Sekolah dengan Fungsi Pelatihan Gradient Descent With Momentum \& Adaptive LR," Jurnal Ilmu Komputer dan Informatika (ALGORITMA), vol. 3, no. 1, pp. 9-20, 2019.

[26] N. Nasution, A. Zamsuri, L. Lisnawita, and A. Wanto, "Polak-Ribiere updates analysis with binary and linear function in determining coffee exports in Indonesia," IOP Conference Series: Materials Science and Engineering, vol. 420, no. 12089, pp. 1-9, 2018.

[27] A. Wanto, "Prediksi Produktivitas Jagung Indonesia Tahun 2019-2020 Sebagai Upaya Antisipasi Impor Menggunakan Jaringan Saraf Tiruan Backpropagation," SINTECH (Science and Information Technology), vol. 1, no. 1, pp. 53-62, 2019.

[28] B. Febriadi, Z. Zamzami, Y. Yunefri, and A. Wanto, "Bipolar function in backpropagation algorithm in predicting Indonesia's coal exports by major destination countries," IOP Conference Series: Materials Science and Engineering, vol. 420, no. 12089, pp. 1-9, 2018.

[29] A. Wanto et al., "Analysis of Standard Gradient Descent with GD Momentum And Adaptive LR for SPR Prediction," 2018, pp. 1-9. 